BASHA'IR

Jurnal Studi Alquran dan Tafsir

\title{
KONSEP KEPEMIMPINAN PEREMPUAN DALAM PANDANGAN ABDUR RAUF AS-SINGKILI
}

\author{
Maulana Razali ${ }^{1}$, Muhammad Mansur $^{2}$, Hanif $^{3}$, Muhajir Al-Fairusy ${ }^{4}$ \\ ${ }^{1,2}$ UIN Yogyakarta, Indonesia, ${ }^{3,4}$ STAIN Teungku Dirundeng Meulaboh, Aceh, Indonesia \\ 1'maulanarazali98@gmail.com, ${ }^{2}$ mansur@uin-suka.ac.id, ${ }^{3}$ hanifmdahlan@staindirundeng.ac.id, \\ 는
}

\begin{abstract}
Abstrak
Tarjuman Al-Mustafid merupakan kitab Tafsir 30 juz pertama di Nusantara, yang menjadi pedoman bagi rakyat Aceh pada masa itu. Kerajaan Aceh Darussalam berdiri pada tahun 1496-1903, berkuasa selama 407 tahun. Dari para pemimpin kerajaan (sultan) terdapat empat orang sultanah yang memimpin secara berturut-turut, dan Abdur Rauf As-Singkili sebagai Qadhi malik al'amin yang diangkat oleh sultanah pertama Sultanah Sri Ratu Tajul Alam Safiatuddin johan berdaulat pada tahun 1661. Abdur Rauf diangkat dan beri tanggung jawab sebagai Qadhi, penasehat, dan serta juru keagamaan kerajaan. Bagaimana pemikiran beliau dalam kitab tafsirnya Tarjuman Al-Mustafid, apakah penafsiran ayat tentang kemimpinan dipengaruhi oleh politik kerajaan?. Penulis tertarik untuk menullis tema ini untuk mengetahui penafsiran ayat-ayat Al-Quran tentang kemimpinan menerut Abdur Rauf As-Singkili, dan untuk mengetahui konsep kepemimpinan perempuan menerut Abdur Rauf As-Singkili. Hasil penelitian membuktikan bahwa penafsiran Abdurrauf tentang pemimpin pada QS. An-Nisa' ayat: 19, 20, 34 dan 58, tidak dipengaruhi oleh politik kerajaan. Abdurrauf tidak menafsirkan bahwa seorang perempuan boleh menjadi seorang pemimpin. Namun aktivitasnya pada kerajaan dengan jabatannya sebagai Kadhi Malik Al 'Adil, Abdurrauf memiliki tanggung jawab sebagai penasehat Sultanah sekaligus sebagai penerapan hukum di Kerajaan Aceh Darussalam. beliau membolehkan seorang perempuan menjadi pemimpin. Hal ini dapat dilihat dalam beberapa peristiwa dan karyanya. Abdurrauf mengeluarkan fatwa untuk menantang kampanye kaum wujudiyah yang berkeinginan untuk menjatuhkan jabatan Sultanah, dan dalam karyanya kitab Miraatul Thulab dalam mukaddimahnya terdapat sanjungan terhadap Sultanah Safiatuddin, "Sultan yang amat besar dan raja yang amat mulia, yaitu paduka Seri Sulthanah Tajul Alam Safiatuddin Syah Berdaulat Dhillullah fi Alam."
\end{abstract}

\begin{abstract}
Tarjuman Al-Mustafid is the first book of Tafsir 30 juz in the archipelago, which became a guide for the people of Aceh at that time. The Kingdom of Aceh Darussalam was founded in 1496-1903, ruling for 407 years. Of the royal leaders (sultans) there were four sultanates who led successively, and Abdur Rauf As-Singkili as Qadhi malik al'amin who was appointed by the first sultanah Sri Ratu Tajul Alam Safiatuddin johan sovereign in 1661. Abdur Rauf was appointed and give responsibility as Qadhi, advisor, and religious interpreter of the kingdom.
\end{abstract}


What are his thoughts in his commentary book Tarjuman Al-Mustafid, is the interpretation of the verse about leadership influenced by royal politics? The author is interested in writing this theme to find out the interpretation of the verses of the Koran about leadership according to Abdur Rauf As-Singkili, and to know the concept of women's leadership according to Abdur Rauf As-Singkili. The results of the study prove that Abdurrauf's interpretation of the leader in QS. An-Nisa' verses: 19, 20, 34 and 58, are not influenced by royal politics. Abdurrauf does not interpret that a woman can be a leader. However, his activities in the kingdom with his position as Kadhi Malik Al 'Adil, Abdurrauf has the responsibility as an advisor to the Sultanah as well as the application of law in the Kingdom of Aceh Darussalam. he allowed a woman to be the leader. This can be seen in several events and his work. Abdurrauf issued a fatwa to challenge the campaign of the embodiments who wished to overthrow Sultanah's position, and in his book Miraatul Thulab in his preamble there is a commendation of Sultanah Safiatuddin, "A very great sultan and a very noble king, namely your Majesty Seri Sulthanah Tajul Alam Safiatuddin Syah Sovereign Dhillullah fi Nature

Keywords: Concept, Women's Leadership, Abdur Rauf As-Singkili

\section{A. PENDAHULUAN}

Dalam Islam, pemimpin disebut dengan khalifah, berasal dari kosa kata bahasa Arab yang bermakna wakil, pengganti atau duta. Dalam pengertian luas, khalifah dimaknai sebagai orang yang bertugas menjaga hukum Islam, selain memimpin umat Islam, dalam rangka penyebaran agama Islam. Khalifah secara ekpslisit adalah estafet dari kepemimpinan Muhammad SAW sebagai Nabi. Dalam konteks sosial, kepemimpinan merupakan kemampuan dan keterampilan seseorang yang menduduki jabatan sebagai pimpinan suatu kerja untuk memperngaruhi prilaku orang lain, terutama bawahannya untuk berpikir dan bertindak sedemikian rupa sehingga melalui perilaku yang positif, ia memberikan subangsih nyata dalam pencapaian tujuan organisasi (Wahjosumidjo, 1987: 24). Dengan demikian, pada setiap kepemimpinan minimal harus ada tiga unsur: pertama seorang pemimpin yang memimpin, mempengaruhi, memberikan bimbingan, dan juga seorang pemimpin menjaga keamanan bagi rakyatnya dengan keamanan yang tinggi (Chalil, 1984, pp. 20-24).

Diskusi kepemimpinan antara laki-laki dan perempuan dalam perspektif gender telah lama berlangsung. Dalam konteks Islam, yang menjadi basis dari studi ini, tidak ada perbedaan dalam soal memimpin antara laki-laki dan perempuan, bagaimanapun sang pencipta menciptakan keduanya untuk menjadi seorang pemimpin. Pemimpin di sini mencangkup makna sangat luas, pemimpin pemerintahan, pemimpin pendidikan pemimpin keluarga, dan pemimpin untuk dirinya sendiri. Syarat paling penting jadi seorang pemimpin adalah menjalankan amanahnya, amanah yang kita emban. Sebagaimana hadist Nabi: "masing-masing kamu adalah pemimpin. Dan masing-masing kamu bertanggung jawab atas yang dipimpinya” (Hadist riwayat Ibn Abbas) (Afifah, 2017).

Akan tetapi, tidak ditemukan konsep kepemimpinan atau harga seorang lelaki dan perempuan itu sama, bisa kita lihat pada masa awalnya Islam dan pra Islam. perempuan dianggap sebagai manusia yang lemah, bahkan kelahiran bayi perempuan dianggap sebagai aib. Malangnya nasib perempuan dikala itu. Ketika Islam datang derajat perempuan mulai diangkat, Rasulullah mengajarkan keadilan sebagaimana sepatutnya hamba Allah yang semuanya sama, tidak ada perbedaan pandangan Tuhan diantara mereka (Chalil, 1984). sesungguhnya Allah hanya melihat amal perbuatan manusia bukan kepada jenis kelamin. Rasulullah membuktikan kasih sayang dan 
cinta kepada perempuan (istrinya) sebagai pedoman bagi para sahabat dikala itu, dan membuat pengaruh pada masyarakat Jazirah Arab.

Transisi kaum perempuan pada masa pra Islam sehingga pasca Islam terjadi perbedaan atas pemberlakuan tindakan terhadap wanita itu sendiri sehingga masa di abad 17 terbukti atas ajaran agama Islam yang mengangkat derajat seorang wanita sehingga mampu menjadi seorang pemimpin kerajaan pada masa itu. Bahkan pada zaman sekarang yang mana kemampuan dan kecerdasan seorang perempuan mampu melampaui kemampuan seorang laki-laki. Di Aceh, sebagai salah satu pusat peradaban Islam yang pernah mencapai titik kejayaannya pada abad ke-17, pernah ada pemimpin dari unsur perempuan. Mereka tampil memimpin Kerajaan Aceh Darussalam.

Kesultanan Aceh Darussalam merupakan sebuah kerajaan Islam yang terdiri di Aceh selama 407 tahun, berawal dari tahun 1496 yang dimulai oleh Sultan Ali Mughyat Syah dan diakhiri oleh Sultan Muhammad Daud Syah pada tahun 1903 (Chalil, 1984, pp. 62-63). Abdurrauf AsSingkili sebagai Mufti Besar Kerajaan yakni Kadhi Malikul Adil pada masa Sultanah Safiatuddin hingga Sultanah Kamalat Syah, yang menegakkan hukum-hukum pada kerajaan dan juga merupakan mufassir pertama di Nusantara pada abad ke 17.

Selama Abdurrauf as-Singkily menjabat sebagai mufti qadhi dalam kerajaan Aceh Darussalam, ia telah menulis sebuah karya tafsir yaitu, Kitab Tafsir Tarjuman Al-Mustafid. Ditulis dalam bahasa Melayu Jawi lengkap 30 juz. Adapun kitab Tafsir Tarjuman Al-Mustafid, Abdurrauf menggunakan penafsiran bi al-Ra'yi (menafsirkan Al-Quran dengan menggunkan nalar) tanpa menyampingkan pendapat atau riwayat dari Sahabat dan Tabi'in. Metode yang digunakan oleh Abdur Rauf dalam menafsirkan Al-Quran adalah metode Tahlily / analisis. Dengan metodi ini Abdur Rauf menjelaskan makna ayat-ayat Al-Quran diseertai dengan asbab nuzul, munasabah, uraian tentang aneka qiraat, makna global ayat dan hukum yang dapat ditarik dari kandungan ayat. Sebelum menafsirkan ayat-ayat, Abdur Rauf terlebih dahulu memberikan keterangan surat yang mekiyah/ madaniyah dan fadhilah al-Surat. Abdurrauf dengan penuh pertimbangan meringkas tafsir Al-Baidhawi dengan dengan membuang uraian-uraian aspek bahasa (lughah) yakni soal i'rab (gramatika) dan juga Aspek balaghah (mani', bayan dan badi') dan jika menyangkut masalah hukum maka Abdurrauf menguatkan paham mazhab Asyafi'i. Dan kitab tafsir ini berkembang luas di Nusantara artinaya dibaca di negeri Siam, Thailand, Kamboja, Filiphina, Malaysia dan di Indonesia terutama di Aceh (As-Singkili, 2011, p. viii).

Beranjak dari itu, Penulis tertarik untuk meneliti ini karena di kalangan umat muslim saat ini, sangat sensitif terhadap kepemimpinan perempuan dengan asumsi bahwasanya "lelaki itu lebih kuat dari pada seorang wanita” (QS. An-Nisa'[3]:34) yang mana Abdur Rauf menjelaskan dalam kitab Tafsir Tarjuman Al-Mustafid bahwasanya ayat ini merupakan penjelasan mengenai suami istri (hukum privat) dan tidak ada kaitannya dengan hukum publik. Dengan hal ini penulis ingin meneliti kitab tafsir Turjumanul Al-Mustafid dan dengan pemikiran Abdur Rauf As-Singkili tentang kemimpinan perempuan selaku Mufti kerajaan Aceh Darussalam di bawah kepemimpinan Sultanah.

\section{B. METODE PENELITIAN}

Dalam penelitian ini penulis menggunakan jenis penelitian library reseach, yaitu memperoleh data dengan menggunakan literatur pustaka yang didasarkan pada data tertulis yang berbentuk jurnal, buku, artikel yang sesuai dengan objek tema yang dikaji. Adapun sifat penelitian 
ini adalah besifat kualitatif, yaitu berdasar pada kualitas data yang telah diuraikan dan dianalisis secara sistematis. Metode pengumpulan data adalah metode atau cara yang digunakan untuk mengumpulkan data yang diperlukan dalam penelitian, agar penelitian dapat terlaksana dengan baik. Sesuai jenis penelitiannya, maka sumber data dari penelitian ini adalah menggunakan sumber primer: diperoleh dari kitab tafsir yaitu kitab tafsir Tarjuman Al- Mustafid dan mengaitkan pemikiran Abdurrauf dengan sejarah kepemimpinan Sultanah dan kepemimpinan perempuan sebelum abad ke 17, dan sekilas menyinggung terhadap adat-istiadat Aceh pada saat itu. Data yang diperoleh menggunakan metode deskriptif-analitik yaitu metode pembahasan dengan cara memaparkan permasalahan dengan analisa serta memberikan penjelasan secara mendalam terkait sebuah data. Penelitian tidak hanya sebatas pada pengumpulan data, namun meliputi analisis dan interpretasi data.

\section{HASIL DAN DISKUSI}

\section{Kepemimpinan Perempuan Aceh Abad Ke- 17.}

Sepanjang catatan sejarah kepemimpinan di Aceh, yang disebutkan munculnya perempuan-perempuan Aceh yang sanggup mengubah kebudayaan memimpin yang berbeda dengan kebudayaan memimpin terdahulunya. Pemaparan ini menghantarkan pembaca untuk mengetahui lebih jauh tentang mengapa sultanah dan sekilas perjalanan kerajaan di bawah kepemimpinan sulthanah. Sultanah Aceh yang pertama yang Safiatuddin yang dikenal sebagai pemimpin perempuan yang sangat dikagumi oleh masyarakat. Sulthanah Safiatuddin adalah anak dari Sultan Iskandar Muda. Sulthan Iskandar Muda memiliki dua orang anak, satu putra dan satu putri. Anak sultan yang putra bergelar Meurah Pupok dan anak Sulthan yang putri bergelar Sri Alam Permaisuri atau disebut sulthanah Safiatuddin (Zulfata, 2015, p. 30). Sulthanah Safiatuddin lahir pada seperempat abad ke 17 atau sekitar tahun 1612-1613. Sejak kecil Sultanah Safiatuddin dikenal sangat baik dan ramah oleh birokrat kerajaan dan masyarakat. Keluarga sultan kerajaan mendapat pembelajaran dan bimbing oleh mufti-mufti kerajaan pada masa pemerintahan ayahndanya, sehingga Sulthanah Safiatuddin memiliki karakter memimpin yang sangat baik (Zulfata, 2015, p. 30).

Sejak usia tujuh tahun, Sulthanah Safiatuddin beserta putra-putri istana lain belajar pada ulama besar seperti Syekh Hamzah Fansuri, Seri Fakih Zainal Abidin Ibnu Daim Mansur, Syeikh Kamaluddin, Syekh Alaidin Ahmad, Syeikh Muhiddin Ali, Syeikh Taqiuddin Hasan, Syeikh Saifuddin Abdul Kahar dan lain-lain merupakan guru besar pada Jami' Baiturrahman (Zulfata, 2015, pp. 30-31). Ratu Tajul Alam Safiatuddin wafat pada tanggal 23 oktober 1675 M. Sebelum acara pemakaman Ratu Safiatuddin dilakukan terlebih dahulu penobatan gantinya, yaitu seri Ratu Nurul Alam Naqiatuddin. Namun cara Naqiatuddin rongrongan dalam negeri, ratu berusaha memperkuat kedudukannya, atau lebih umum lagi kedudukan pemerintah pusat (kesultanan), antara lain dengan mengadakan perubahan-perubahan dalam beberapa pasal qanun Meukuta Alam (Undang-Undang Dasar Keajaan.

Setelah pemakaman Seri Ratu Nurul Alam Naqiatuddi dilaksanakan, maka terlebih dahulu dinobatkan penggantinya, yaitu Sultanah Zakiatuddin Inayat Syah. Sebagaimana Ratu Safiatuddi telah mempersiapkan Naqiatuddi sebagai penggantinya, dan begitu pula sejak Rati Naqituddin telah mempersiapkan putri Raja Setia untuk penggantinya, yang kemudian setelah dinobatkan bergelar SultanahSeri Ratu Zakiatuddin Inayat Syah. Pada hakikatnya Sultanah Safiatuddi sebenarnyaa telah mempersiapkan tiga orang perempuan istana sebagai penggantinya kelak, ketiga putri bangsawan ini 
telah didik dalam Kerato Darut Dunia dengan berbagai pendikan khusus dan berbagai ilmu pengetahun yang mereka terima : ilmu Hukum termasuk hukum tatanegara, sejarah, filsafat, kesusastaraan, pengetahuan agama islam, bahasa Arab, bahasa Persia, bahasa Spanyol dan bahasa Inggris. Mereka adalah Ratu Nakiatuddin, Zakiatuddin dan Kamala (Hajmy, 1977, p. 199)t.

Kebijakan-kebijakan yang dijalankan oleh Ratu Safiatuddin dan Ratu Naqiatuddin terus dijalankan. Ratu zakiatuddin tidak memberi ampun bagi kaum yang wujudiah bahkan mengambil kebijakan-kebijakan bijak untuk menghilagkan kaum tersebut. Den juga bagi Konsi Perdagangan Belanda (VOC) yang semenjak pemerintahan Ratu Safiatuddin terus merejalela hingga pada masa pemerintahan Ratu Zakiatuddin. Ratu Zakiatuddin tidak sama sekali memberi hati bahkan memperkihatkan giginya (Hajmy, 1977, p. 200.). Disamping dalam menghadapi berbagai tantangan, Ratu Zakiatuddi bertindak cepat untuk memajukan pendidikan dan ilmu pengetahuan. Semua pusat pendidikan baik dayah atau pendidikan tinggi semuanya dibina dengan sangat baik. Dan dibangun dayah-dayah baru, sementara Pusat pendidikan Tinggi Baiturrahman dikembangkan terus di bawah pimpinan Syekh Abdur Rauf As-Singkili dan ulama-ulama lainnya. Menunasah dan mesjid dibina dan ditingkatkan fungsinya, sehingga ajaran-ajaran agama Islam merata ke dalam jiwa rakyat (Hajmy, 1977, p. 291).

Selama memerintah, Ratu Zakiatudin telah berbuat banyak untuk mempertahankan kebersaran Aceh. Sekalipun Baginda tidak sanggup mengembalikan Aceh pada martabat seperti di zaman Iskandar Muda. Akan tetapi sang Baginda Ratu mampu mempertahankan kedaulatan Aceh seperti waktu diwarisinya, bahkan dalam beberapa hal telah dapat ditingkatkan kembali. Setelah memerintah sepeluh tahun, Sultanah Seri Ratu Zakiatuddin Inayat Syah wafat pada hari ahad tanggal 8 Zulhijjah 1098 H. (3 Oktober 1688 M) (Hajmy, 1977, p. 208).

Jika dilihat dari nilai-nilai hukum kerajaan jelas berbeda dikarena dengan kepercayaan yang berbeda dan juga disebabkan oleh politik kerajaan. Seperti Kerajaan Aceh Darussalam ketika Sultanah memimpin kerajaan Aceh terdapat nilai-nilai agama di dalam dasar undang-undang kerajaan Aceh bahkan ini berlaku sampai sekarang sebagai daerah yang menjunjung tinggi nilai agama untuk rakyatnya. A. Hasjmy juga mengatakan dalam bukunya yang berjudul "59 Tahun Aceh Merdeka di bawah Pemerintahan Ratu” sejak dari kerajaan Islam Perlak, Kerajaan Islam Samudra Pase sampai kepada Kerajaan Aceh Darussalam, Ajaran agama Islam telah diambil sebagai dasar Negara, dan sumberi hukumnya, yaitu; Qur'an, Sunnah, Ijma' dan Qiyas (Hajmy, 1977, p. 21).

Pada masa Ratu Balence pada abad ke -12 merupakan masa gilang-gemilang di Francis, namun hal yang tidak diinginkan oleh kerajaan terjadi, yaitu adanya kaum bid'ah yang menantang agama yang di anut oleh kerajaan yaitu kristen ortodok. Hal ini sungguh tantangan yang besar bagi kerajaan, karena bangsa sendiri itu sangat dekat dengan kerajaan dan mengetahui selak beluk negerinya sendiri, setidaknya jika mereka menyerang maka merekan akan mudah sekali untuk memulai tindakan pertama. Namun hal ini mampu ditangani oleh pendeta kerajaan besar Paus. Namun hal demikian juga terjadi di Kerajaan Aceh Darussalam, pada masa Sulthanah Safiatuddin dan Naqiayatuddin, dan Mampu ditangani oleh Kadhi Kerajaan yaitu Abdurrauf As-Singkili dan ulama besar Nuruddin Ar-Raniri (Hajmy, 1977, pp. 167-185.).

Pada masa Ratu Kalinyamat, ia merupakan anak Sulthan Tranggana satu-satunya. Atas kepercayaan pihak kerajaan terhadap Ratu Kalinyamat dan memberikan hak kerajaan Jepara kepada Ratu Kalinyamat yang memimpin pulau jawa. Kerajaan Jepara ini juga salah satu Kerajaan yang pernah bersilaturrahmi dengan Kerajaan Aceh Darussalam, Ratu Kalinyamat pernah menolong dan 
mengirimkan bantuan perang kepada Kerajaan Aceh dibawah kesultanan Alaidin Riyat Syah yaitu Sulthan Kerajaan Aceh Darussalam yang ke-3.

\section{Pemikiran Abdurrauf As-Singkili Tentang Kepemimpinan Perempuan}

Dibalik kokohnya peradaban Kerajaan Aceh Darussalam, terdapat suatu undang-undang yang memperlakukan perempuan dengan sebaiknya, terutama dampak daripada pandangan Abdurrauf As-Singkili sebagai seorang tokoh agama yang sangat dihormati. Ia juga menerangkan dan memberi pembinaan kepada perempuan. Berikut beberapa pandangannya terhadap perempuan;

Pertama, beranjak dari surah An-Nisa' ayat 19. Dalam ayat ini Abdurrauf mengangkat martabat seorang perempuan (istri) yang mana seorang suami yang ingin menjahatinya dan menyakiti hatinya dengan berzina dengan wanita lain atau pergi meninggalkannya maka dari hukuman dari perbuatannya itu adalah akan didenda dan diceraikan dengan istrinya. Abdurrauf juga menerangkan asbabul wurud dari ayat itu sebagai berikut:

"...bahwasanya pada masa jahiliyah diwarisi adat mereka itu bangsa arab pada masa itu, jika seorang lelaki mengawini seorang perempuan mereka tidak memberikan mahar. Maka dengan itu Allah menegakkan atas demikian itu. Dan juga mengatakan tidak halal bagi seorang suami menikah dengan lainnya sedangkan dia tidak gemar kepada istrinya karena dengan hal ini akan menyakiti hati seorang istri. Maka jinaklah mereka itu dengan segala hal yang elok pada pekataan yang baik dan bermalam. Dan jika terdapat kebencian terhadap mereka itu maka besabarlah maka mudah-mudahan kamu dijadikan di dalamnya kebajikan (As-Singkili, 2011, pp. 246-247).

Kemudian pada ayat selanjutnya Abdurrauf menafsirkan:

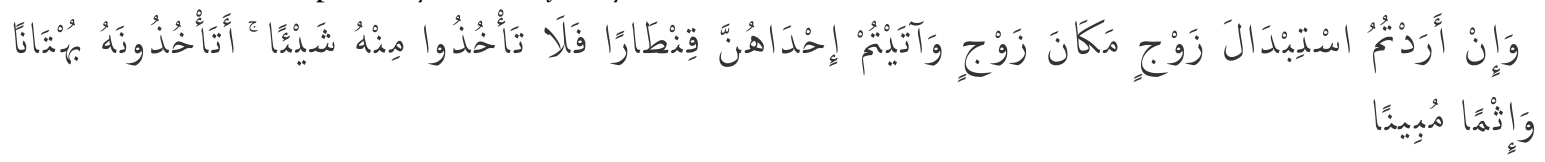

dan jika kamu menghendaki menggantikan suatu istri dan telah kamu berikan mahar yang banyak, maka jangan kamu ambilkan kembali daripadanya satu juapun. (Q.S. An-Nisa': 20). (As-Singkili, 2011, p. 247)

Pandangan Abdurrauf terhadap seorang wanita begitu hangat, yang selalu dijunjung terhadap martabatnya baik di masyarakat, di keluarga, bahkan dalam politik sekalipun. Demikian penafsiran Abdurrauf dalam ayat diatas tentang bagaimana memperlakukan terhadap calon istri yang ingin dinikahi dengan memberikan mahar, dan jangan sampai menyakiti hatinya dengan segala perbuatan yang keji dan jika kamu mendapatkan hal-hal yang membuatmu benci maka besabarlah semoga kebencian itu dijadikan didalamnya kebajikan.

Apabila menceraikan istri, tidak diperbolehkan untuk mengambil maharnya kembali, karena hal ini membuat seorang istri rasa kasihan. Karena dalam hubungan suami dan istri seorang suami yang berkewajiban mencari nafkah dan merupakan kebiasaan bagi kaum laki-laki dan seorang istri tidak berkewajiban untuk hal itu, jika mahar tersebut tidak diambil maka tidak merasa rugi bagi seorang mantan suami karena bisa mencari lagi sedikit harta itu.

Namun pada penafsiran ayat tersebut juga berkaitan dengan hukum negara yang diterapkan Qanun Meukuta Alam. Sebuah undang-undang yang dibuat oleh Sultanah Safiatuddin dengan kebijaksanaan ketuanya Kadhi Malikul Adil Abdurrauf As-Singkili dan menjadikan undangundang yang sah. Adapun isi undang-undang tersebut antara lain: 
konsep kepemimpinan perempuan dalam pandangan abdur rauf as-singkili

1) Tiap-tiap orang tua haruslah menyediakan sebuah rumah kepada anaknya perempuan, kalau dia sudah dipersuamikan, rumah itu diserahkan menjadi milik si anak.

2) Juga harus diberi barang sepetak sawah, sebidang kebun dan seutas emas

3) Si suami harus membawa sepetak sawah (umong Peuneuwou) kepada isterinya dan menjadi hak milik si istri dan sekedar pakaian emas

4) Si suami harus tinggal bersama istri di rumah istrinya.

5) Selama mereka masih tetap hidup rukun dan damai, maka segala harta itu (rumah, sawah kebun yang berasal dari kedua pihak) menjadi milik bersama.

6) Harta kekayaan yang didapatinya selama masa dalam perkawinan adalah menjadi milik bersama, artinya 50\% milik suami dan 50\% menjadi milik istri.

7) Apabila menjadi perceraian maka si suami harus pergi dari rumah istrinya, dan harta-harta pembawaannya (sawah, kebun dan sekedar perhiasan emas) waktu dia mula-mula kawin, harus ditinggal menjadi hak si istri, sementara harta yang didaapatinya selama masa perkawinan dibagi dua, yaitu 50\% boleh dibawanya.

8) Selama masa iddah perceraian, segala nafkah hidup si istri menjadi tanggung mantan suami (Hajmy, 1977, pp. 127-128).

Dari qanun diatas dapat penulis simpulkan bahwa terdapat persamaan qanun dengan penafsiran Q.S. An-Nisa' ayat 19-20. Abdurrauf menginginkan martabat wanita tidak buruk yang tidak kita inginkan dan mengankat martabat seorang wanita demi kemaslahatan bersama dengan adil.

Penafsiran Abdurrauf pada ayat An-Nisa' ayat 19 dan 20 adalah anjuran untuk memberi mahar untuk mempelai perempuan Dan larangan untuk mengambil kembali atas mahar yeng telah diberikan itu. Dalam qanun juga terdapat anjuran dan larangan yang sama, yaitu bagi mempelai lakilaki harus memberikan sepetak sawah, seutas emas dan larangan mengambil kembali apa yang diberikan jika terdapat massalah dan terjadi perceraian, harta pencarian suami dibagi setengah milik suami dan setengah lagi milik istri.

Bagaimana pun kitab tafsir Tatjuman Al-Mustafid dituliskan ketika Abdurrauf menjabat sebagai penasehat Sultanah dan mufti kerajaan yang menetapkan hukum (Qadhi Malik), berangkat dari jabatannya sebagai penjabat kerajaan (Qadhi Malik), maka beliau menuliskan penafsiran ini tidak menyinggung sedikitpun dengan kata kepemimpinan, akan tetapi Abdurrauf menjelaskan tentang hubungan suami istri saja.

Kedua, fatwa lain yang Abdurrauf keluarkan untuk mempertahankan kepemimpinan Sultanah sebagai berikut:

1) Syekh Nuruddin Ar-Raniry bersama Abdurrauf As-Singkili mengeluarkan fatwa untuk membantah kaum wujudiyah yang ingin menjatuhkan kedudukan Sultanah, yang menyatakan bahwasanya menurut hukum Islam seorang wanita tidak boleh menjadi pemimpin. Dengan alasan ini fatwa dikeluarkan untuk menyatakan: bahwa wanita dalam Islam sama derajat dengan pria dan berhak menjadi raja (Hajmy, 1977, p. 177).

Dan seorang perempuan mampu menjadi seorang pemimpin selayaknya seorang pria dan berhak menjadi pemimpin. Namun tidak dapat dipungkiri seorang perempuan juga mampu memimpin negri. Setelah penulis teliti ternyata emang terdapat 
Maulana Razali, Muhammad Mansur, Hanif, Muhajir Al-Fairusy

beberapa pemimpin dalam kerajaan Aceh dengan sosok perempuan. Adapun beberapa pemimpin perempuan yang berkuasa pada kerajaan Aceh sebagai berikut:

a) Puteri Lindung Bulan, anak bungsu dari Raja Muda yang memerintah kerajaan Benua / pada tahun 753-800 H. (1333 - 1398 M.)

b) Ratu Nihrasiyah Rawangsa Khadiyu, yang menjadi ratu terakhir dari Kerajaan Islam Samudra Pase yang memerintah pada tahun 801-831 H. (1400 - 1428 M.).

c) Laksamana Malahayati, seorang janda muda yang menjaddi panglima dari Armada Inoengbale (Armada Wanita Janda), yang dibangun oleh Sulthan Alaiddin Riat Syah Saidil Mukammil, yang memerintah dalam tahun $997-$ 1011 H. (1589 - 1604 M.).

d) Ratu Safiatuddin, memerintah Kerajaan Aceh Darussalam pada tahun 1050 - 1086 H. (1641 - 1675 M.).

e) Ratu Naqiatuddin, memerintah Kerajaan Aceh Darussalam pada tahun 1086 - 1088 H. (1675 - 1678 M.)

f) Ratu Zakiatuddin, memerintah Kerajaan Aceh Darussalam pada tahun 1088 - 1098 H. (1678 - 1688 M.).

g) Ratu Kamalat, yang memerintah Kerajaan Aceh Darussalam pada tahun 1098 - 1109 H. (1688 - 1699 M.).

h) Cut Nyak Dhin, yang memimpin armada perang setelah suaminya, Teuku Umar syahid.

i) Teungku Fakinah, seorang wanita ulama yang menjadi pahlawan memimpin sebuah resimen Aceh.

j) Cut Mutia, seorang pahlawan wanita yang selama 20 tahun memimpin perang gerilny dalam hutan pase, yang kemudian syahid.

k) Pocut Baren, yang memimpin perang terhadap pasukan Belanda pada tahun (1898 - 1906 M.).

1) Pocut Meurah Intan, seorang pahlawan wanita yang memimpin perang melawan Belanda pada tahun 1904 M.

m) Cutpo Fatimah, seorang pahlawan perempuan mememimpin peperangan dengan suaminya hingga tahun 22 Februari 1912 (Hajmy, 1977, pp. 25-26).

Ketiga, Abdurrauf as-Singkili mengadakan dakwah meluas kepada rakyat menyatakan bahwa wanita dalam Islam sama derajatnya dengan kaum pria dan mempunyai hak yang sama. Dakwah ini terus dilaakukan oleh Abdurrauf kepada rakyat Aceh sehingga yang menolak kepemimpinan wanita dapat dikendalikan. Mendakwah kepada rakyat Aceh untuk memperjelaskan tentang fatwa baru yang dikeluarkan olehnya.

"bahwa wanita dalam Islam sama derajat dengan pria dan berhak menjadi raja" (Hajmy, 1977, p. 177).

Hal ini dilatarbelakagi oleh kaum wujudiyah yang melakukan kampanye yang mefatwakan bahwasanya menurut hukum Islam, perempuan tidak boleh menjadi raja. Dengan hal ini Abdurraauf langsung mengeluarkan fatwa tersebut untuk melindungi kedudukan Sultanah (Hajmy, 1977, p. 17). Namun untuk kerincian isi dakwahnya sejauh ini penulis tidak temukan dalam beberapa sumber rujukan sejarah Aceh dan dalam kitab Qanun Aceh yang membahas kerincian keseluruhan isi dakwah Abdurrauf tersebut untuk melindungi jabatan Sultanah dan beliau selaku 
mufti kerajaan, yang menegakkan hukum Islam pada kerajaan Aceh Darussalam. Dari pada itu juga Abdurrauf ingin mendamaikan terhadap ulama-ulama Aceh yang bertentangan dengan kepemimpinan perempuan.

\section{KESIMPULAN}

Beranjak dari uraian di atas, perempuan dalam pandangan Abdurrauf As-Singkili memiliki hak untuk memimpin. Peranan Abdurrauf membela Sultanah yang telah dijelaskan sebelumnya dapat diremuskan ke 2 poin penting:

Pertama, Penyebab Abdurrauf As-Singkili membolehkan kepemimpinan perempuan dengan berpendapat bahwasanya perempuan dalam Islam sama derajat dengan lelaki dan berhak menjadi raja. Selama sang raja melakukan segala hukum-hukum Allah.

Kedua, Penafsiran Abdurrauf As-Singkilli tentang Kepemimpinan Perempuan tidak dipegaruhi oleh politik dan tidak menyinggung tentang kepemimpinan Perempuan. Akan tetapi, dalam menafsirkan surat An-Nisa' ayat 34 beliau menafsirkan bahwa makna "Ar-Rijal" itu adalah suami yang mana penafsiran ini dibatasi oleh lingkup keluarga dalam berumah tangga saja, yang mana suami sebagai pemimpin rumah tangga. Beliau tidak menafsirkan makna lelaki secara umum yang menjadi menolaknya kepemimpinan perempuan.

\section{DAFTAR PUSTAKA}

Afifah, N. D. (2017). Islam, Kemimpinan Perempuan, dan Seksualitas, (Jakarta :Yayasan Obor Indonesia, 2017). Jakarta: Yayasan Obor Indonesia.

As-Singkili, S. A. (2011). Turjumanu Al-Mustafid (Vol. 1). (I. Thalib, Trans.) Beirut.

Chalil, M. (1984). Nilai Wanita. Solo: Rahmadani.

Fathurrahman, O. (1999). Tanbih Masyi Menyoal Wahdatul Wujud, Kasus Abdur Rauf singkel di Aceh Abad ke 17, Tesis Universitas, Bandung 1999. Bandung: Mizan.

Hajmy, A. (1977). 59 Tahun Aceh Merdeka dibawah Pemerintahan Ratu. Jakarta: Bulan Bintang.

Harun, S. (1988). "Hakikat Tarjuman Al-Mustafid". Jakarta: Perpustakaan IAN Syarif Hidayatullah Jakarta.

Hasjmy, A. (1983). Kebudayaan Aceh dalam Sejarah . Jakarta: Penerbit Benua.

Riddel, P. G. (1984). "A Critical Study Of Juz 16”. Autralia: Menziez Librii building.

Ridha Hayati. (2017). Resepsi Hermeneutis Mufassir Tanah Rencong terhadap Ayat-Ayat Al-Quran Tentang Cambuk. UIN Sunan Kalijaga. Yogyakarta: UIN Sunan Kalijaga. 
Rukiah. (2015). penafsiran surat Yasin Abdur Rauf As-Singkili (Kajian atas Kitab Tafsir Tarjumanu AlMustafid. UIN Sunan Kalijaga, Fakultas Ushuluddin. Yogyakarta: UIN Sunan Kalijaga.

Subhan. (2011). Metode dan Corak penafsiran Abdur Rauf As-Singkili , 2011). UIN Sulthan Syarif Kasim . Riau: UIN Sulthan Syarif Kasim .

Zulfata. (2015). Jejak Sultanah Safiatuddin. Kediri: Fam Publishing. 